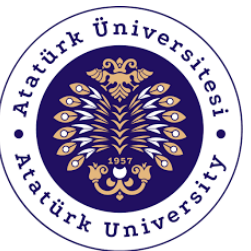

\author{
Doğu Coğrafya Dergisi \\ Aralık-2019, Yı1: 24, Say1: 42, Sayfa: 79-90 \\ Eastern Geographical Review
}

December-2019 Volume: 24, Numbers: 42, Page: 79-90

DOİ: https://doi.org/10.17295/ataunidcd.627283

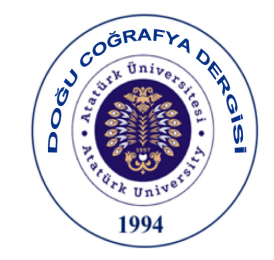

Attf/Citiation

GÜNER, B.,(2019), “Yüzen Evler” Olgusuna Genel Bir Bakış ve Keban Baraj Gölü Örneği. Doğu Coğrafya Dergisi 24(42), 1-15

\title{
“YÜZEN EVLER" OLGUSUNA GENEL BİR BAKIŞ VE KEBAN BARAJ GÖLÜ ÖRNEĞİ
}

A General Outlook on The Fact of 'Floatıng Houses' and Keban Dam Lake Case

Dr. Öğr.Üyesi Bülent GÜNER ${ }^{1}$

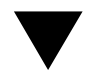

$\ddot{O} z$

Yüzen evler, su yüzeyinde yatay veya dikey yönlü hareket edebilen, belirli amaçlar için özel olarak tasarlanmıs meskenlerdir. Dünyanın çeşitli okyanus, deniz, göl ve akarsularında çok çeşitli nedenlerle inşa edilen yüzen evler, kirsal ve kentsel meskenler olarak kullanılmaktadır. Yüzen evlerin yaygınlaşmasinda; yerleşim birimlerini tehdit eden sel baskınlarl ve deniz seviyesi yükselmeleri gibi doğal etkenlerin yanı sira, hizl kentleşme ve ekonomik faaliyetler gibi beşeri etkenler de öne çılkmaktadır. Yüzen evler ayrıca kentlerden uzak, doğa ile iç içe bir yaşam seçeneği sunduğu için gün geçtikçe turizm sektöründen ve çevrecilerden daha fazla ilgi görmektedir. ABD, İngiltere, Hollanda, Kamboçya ve Filipinler yüzen evlerin yayginlaşttğı ülkelerdir.

Türkiye'nin kültür balıkçıllğı yapılan deniz ve göllerinde dalyan yerleşmeleri olarak ortaya çıkan yüzen evler, 2007 yllından beri yayginlaşmaktadır. Ülkemizde bulunan yüzen evler, dalyanların işlevlerine sahip olmaları nedeniyle; dönemlik/geçici yerleşmeleridir. Keban Baraj Gölü, ülkemizde yüzen evlerin son ylllarda saylsının arttığ alanlardan biridir. Bu meskenler, balık çiftliklerinde çalışanların barınağı ve balıkçıllk faaliyetinin gereksinimlerini karşılayan bir lojistik deposu olarak kullanılmaktadır.

Dünyada ve Türkiye'de gün geçtikçe ilgi gören bir kırsal mesken türünü, Keban Baraj Gölü'ndeki örnekleriyle incelemek, çalı̧̧mamızın temel amacin oluşturmaktadır. Bu kapsamda olgu, benzerlik ve farklılıklarıyla küreselden yerele doğru ele alınmıștır. Dünyadaki örneklerinden anlaşıldı̆̆ üzere çok farkl amaçlarla kullanılan yüzen evler, ülkemizde kültür balıkçılı̆̆ına bağll olarak yayginlaşmaktadır.

Anahtar Kelimeler: Yüzen Evler, Keban Baraj Gölü, Kültür Balıkçıllğg

\section{Abstract}

Floating houses are dwelling places which can horizontally or vertically move and are designed for specific aims. Floating houses which have been built in many ocean, sea, lake, and streams of the world are used as rural and urban settlements. Human factors such as rapid urbanization and economic activities shine out in floating houses to be popular besides natural factors like eustacy and floods which threaten the locations. Moreover, since floating houses offer a living option to be with nature free from the cities, they have gradually attracted attention by the tourism sector and environmentalists. USA, UK, Netherlands, Cambodia, and the Philippines are the countries where floating houses become popular.

\footnotetext{
${ }^{1}$ Munzur Üniversitesi, Edebiyat Fakültesi, Coğrafya Bölümü. E mail: bguner@munzur.edu.tr), ORCID ID: 0000-0003-1893-7216
} 
Floating houses which emerge as dalyan on Turkey's sea and lakes with aqua fishing have become widespread as from 2007. Floating houses in our country are temporary settlements because of being have the functions of dalyans. Keban Dam Lake is one of the places where the number of floating houses gradually increases in recent years. These settlements are utilized as the shelter of workers of fish farms and also logistics warehouse that meets the needs of fishing activities.

The chief goal of our study was to review the rural settlement type that has attracted attention day by day in Turkey and the world by its examples in Keban dam lake. In this sense, the related fact was scrutinized by similarity and differences from global to local. As is understood by the examples world-wide, floating houses which are used by quite a change purposes have become widespread based on aquafishing activities in our country.

Keywords: Floating Houses, Keban Dam Lake, Aqua Fishing 


\section{Giriş}

Yüzen ev; deniz, göl gibi büyük su kütlelerinin yüzeyinde yatay /dikey yönde hareket edebilen ve bir yüzdürme platformu üzerine kurulan bir mesken türüdür. Buna göre yüzen ev konseptinin, evlerin hareket kabiliyetine göre iki türü bulunmaktadır. İlki, temel bağlantısıyla karasal zemine bağlı (lokasyonu değişmeyen) evlerdir. Bu evler çeşitli doğal etkenlerle su yüzeyinin yükselip alçalmasına bağlı olarak, 3 ile 6 metre dikey yönlü hareket edebilen mekanizmalara sahip; akarsu, göl, deniz ve okyanuslarda ya da kıyılarında (karada) bulunan "amfibi” evlerdir. Amfibi evler, dünyada en yaygın görülen yüzen ev türüdür. Bu meskenler, çeşitli malzeme ve mimarilerle, çok çeşitli kullanım amaçlarıyla ABD, Hollanda, İngiltere, İtalya, Yeni Zelanda, İsveç, Kanada, Bangladeş, Filipinler ve Kamboçya'da yaygındır. Küresel ısınmaya bağlı deniz seviyesi yükselmelerinin, yerleşim birimlerini tehdidine karşı bir seçenek olarak önerilen bu meskenler, özellikle taşkın, sel, gelgit, kasırga nedeniyle oluşan su baskınlarının yaşandığı bölgelerde de ilgi görmektedir. Dolayısıyla amfibi evler, çeşitli doğal etkenlerle oluşan su baskını hasarını azaltmak ve milyonlarca insanı mağduriyetten kurtarmak için kitlesel bir çözüm sunmaktadır. Ayrıca kıyıların betonlaşmasına alternatif olarak kullanılabilecek turistik bir mesken, balıkçılık faaliyeti için pratik bir barınak ve topraksız yoksullar, mülteciler gibi büyük gruplar için bir ikamet imkânı olarak görülmektedir. İkinci tip yüzen evler ise karasal zemin ile herhangi bir bağlantısı bulunmayan (lokasyonu değişebilir), su yüzeyinde yatay hareket (mobilite) edebilen ve "gezici / gezen evler" olarak da adlandırılan ve yaygın olarak balıkçılık faaliyetinde ya da turizm amacıyla kullanılan mesken türüdür (Ishaque ve ark.,2014: 5056), (Ramsey ve ark., 2018: 1-10), (Ambica ve Venkatraman, 2015:1-4), (Moon, 2015: 98-101).

Yüzen evlerin hukuki prosedürleri henüz tartışılmaktadır. Doğal olarak bir olgunun hukuki metinlerde yer alması, olgunun ortaya çıkışı ve kökleşmesine bağlı olarak gerçekleşmektedir. Konu üzerine dünyada yapılan çeşitli hukuki tartışmalar, "yüzen evler" kavramının pek çok açıdan değerlendirilmesi gereken karmaşık bir olgu olduğunu ortaya çıkarmıştır. Örneğin meskenlerin taşınır veya taşınmaz olarak değerlendirilmesi ve buna göre bir yasal çerçeve oluşturulması, konunun bir yönünü oluşturmaktadır. Bu bağlamda yüzen evlerin, yüzen bir yapı olarak menkullüğü / gayrimenkullüğü tartışılmaktadır. Hukuki değerlendirmelerin bir başka yönünü ise konut inşaatının yasal çerçevesi, yerleşmenin tanımı, alım-satımı, tapu kaydına işlenişi, "arsa payları" gibi mülkiyet edinimi ile ilgili mevzuatlar ve yüzen evlere yerleşim ruhsatı verilebilmesi için gerekli teknik şartlar oluşturmaktadır. Öte yandan yüzen evlerin alması gereken kamu hizmetleri, vergilendirilmeleri, deniz / akarsu trafik güvenliğinin sağlanması, sağlık, emniyet, çevre koruma, çöp, su arıtma, kanalizasyon ve atık yönetimi ile ilgili konular ise hukuki açıdan tartışılan diğer sorunlardır (MDDPC, 2010), (Dambite, 2011: 76-77).

Yüzen evler, görece yeni bir dizayn ve mimari / mühendislik alanı olarak kendine özgü ihtiyaçlarıyla ortaya çıkmaktadır. Örneğin elektrik enerjisine uzak bölgelerdeki yüzen ev yapılaşması, kendine yetebilen enerji sistemlerini zorunlu k1lmaktadır. Rüzgar, gelgit, dalga gücü ve güneş enerjisine entegre halde enerji üretebilen hibrid teknolojiler, yüzen evler açısından da önemi artan gelişmelerdir. Ayrıca taşınabilir muhtelif ev-portatif sistemleri, gelişmiş bir su geri dönüşüm ve 1sınma sistemi yüzen evlerin kullanışlığını artıran donanımlardır.

Yüzen evlerin dünyadaki örneklerine bakıldığında en iptidaisinden en donanımlısına, meskenin şeklini, yapı malzemesini ve konforunu belirleyen ana unsurlar; ülkelerin refah düzeyi, bölgesel gereksinimler ve yerel niteliklerdir. Bu bağlamda dünyanın çeşitli yerlerinde inşa edilen yüzen evlerde, bambu dallarından ahşaba, plastik malzemeden metal ve betonarme malzemelere çok çeşitli yapı unsurları kullanılmaktadır. Donanımlı / konforlu yüzen ev yapımında ise Hollanda ve Kanada yatırımları ve teknolojisi öne çıkmaktadır. Özellikle Hollanda hem konut teknolojisi hem de modern yapılaşma açısından öndedir. Örneğin Ijburg kentinde 75 adet yüzen evden oluşan bir site bulunmaktadır (Moon, 2015: 98-101).

Dünyadaki bazı kentler doğal nedenlerle su baskını riski altındadır. Bu bakımdan bu kentler için amfibik evler bir çözüm yolu olarak görülmektedir. Avrupa'da küresel iklim değişimiyle artan sel vakaları ve küresel 1sınmaya bağlı olarak deniz seviyesi yükselmesi; Hamburg, Londra, Amsterdam ve Stockholm gibi liman kentlerini tehdit etmektedir. Örneğin Londra metropol alanının \% 15'i nehirlerin taşkın alanlarında bulunmaktadır. Yine Londra'da yüksek gelgitler, 1.25 milyondan fazla insan ve yaklaşık 500.000 bina için risk oluşturmaktadır. Asya'da ise Filipinlerin başkenti Manila çeşitli nedenlerle yüzen evlere ihtiyaç duyan bir başka kenttir. Manila, hızla artan nüfusuna karşın, konut yapımı için arsa/arazi arzının yetersiz kalması sorunuyla karşı karşıyadır. Ayrıca sık sık yaşanan firtınalar sonucunda oluşan su baskınları da Manila için bir başka sorundur. Bu nedenle "firtınaya dayanıklı" yüzen evler Manila'da çözüm olarak gündemdedir (Schroder, 2015: 44-49), (Ramsey ve ark., 2018: 110), (Naing ve ark., 2011: 69-74). ABD'de ise Katrina ve İrma kasırgalarından sonra özellikle Florida ve Miami gibi güney kıyı kentlerinde lüks donanımlı, modern, dayanıklı yüzen evlere ilgi artmışıtır (Garfield, 2017). ABD'nin kuzey kentlerinde ise yüzen evler daha çok göllerde ve nehirlerde bulunmaktadır. Vancouver, Victoria, Seattle, Portland ve San Francisco gibi Kuzeybatı Pasifik kıyı yerleşmelerinde yüzen evler yoğunlaşmaktadır (Moon, 2015: 98-101). 
Dünyada yaygın görülen yüzen ev tipi “amfibik evler” olsa da, Türkiye'de görülen örneklerin tamamına yakını, kültür balıkçılığına uygun olarak yatay yönlü hareket edebilen, "gezen ev"lerdir. Ülkemizde kültür balıkçılığı dışında başka amaçlarla bu meskenleri yapmak yasal olarak mümkün değildir. Türkiye'deki ilk yüzen ev örnekleri, Çevre ve Şehircilik Bakanlığı'nın çeşitli çevresel uygulamaları sonucunda, kültür balıkçılı̆̆ı yapılan denizlerde, Mersin ve Muğla kıyılarının yakınında inşa edilmiștir. Bakanlık 2007 yılında yayınladığı esaslarla, denizlerde kültür balıkçılığı faaliyetlerine çeşitli sınırlamalar getirmiş ve genel olarak kıyıdan $1 \mathrm{~km}$ mesafeden itibaren balık çiftliklerinin kurulmasına izin vermiştir (Resmi Gazete, 2007). Balık çiftliklerinin karadan uzaklaştırılması, balık kafeslerinin bakımı için gerekli olan günlük ihtiyaçların teminini güçleştirmiş, işgücü ile ilgili bir takım sorunların da ortaya çıkmasına neden olmuştur. Karadan uzaklaşan tesislerin ulaşım maliyetlerindeki artış, son 10 yılda yüzen evlere gereksinimi artırmıştır (Sözcü Gazetesi, 2017), (Paratic, 2016), (Steemit, 2017).

Son yıllarda yüzen evlerin hızla artış gösterdiği önemli bir iç su alanımız Keban Barajı'dır. Barajda kültür balıkçılığının gelişmesi ve profesyonelleşmeyle birlikte yüzen evler de yaygınlaşmıştır. Bu yaygınlaşma "birkaç yıl" olarak ifade edilebilecek bir sürede gerçekleşmiştir. Bu gelişme çalışma alanı için oldukça yeni bir durumdur.

\section{Bulgular}

Modern çağ; ortaya çıkardığı yeni ihtiyaçlarla, kitleselleşen tüketimle ve gelişmiş teknolojiyle, kırsal alanda yeni bir süreci başlatmıştır. Her şeyden önce hızla artan dünya nüfusu, kırsal alan üstünde ciddi bir üretim baskısı kurmuştur. Ekstansif tarım anlayışı, uzunca bir süredir yerini şirketlere ait çiftliklere ve plantasyonlara bırakmaktadır. Böylece kırsal alanda yeni bir dinamik gelişmekte ve yeni bir kırsal doku oluşmaktadır. Bugün ülkemizin kırsal alanları bir ölçüde bu yeni üretim biçimiyle şekillenmektedir. Türkiye'de aile işletmeciliğine dayanan geleneksel hayvancılık faaliyeti, bir süredir büyük sermaye yatırımlarıyla kurulan büyük çiftliklerin uğraşısı olurken, köylülerin üretimi yerini profesyonel çiftliklerin üretimine bırakmaktadır. Artık köy evinin yanında bulunan kümesin üretimini büyük ölçüde tavuk çiftlikleri gerçekleştirmekte, evin altındaki ahırın yerini geniş arazilere kurulu müstakil ahırlar almakta ve avcı balıkçılık yerini çiftlik balıkç1lı̆ına terk etmektedir.

Türkiye kırları on y1llardır verdiği göçlerle sürekli olarak güç yitirse de; mevcut potansiyeliyle, yeni kırsal yapılar ortaya çıkarma / dönüştürme yeteneğine sahiptir. Geleneksel kırsal yapıyla; teknoloji kullanımı ve şirketleşmiş üretim biçimi yan yana gelerek yeni bir sentez oluşturmaktadır. Bunun sonucunda kırsalda yeni bir "modern" oluşmakta ve yalnızca geleneksel bir üretim biçimi dönüşmemekte, yeni bir yaşam tarzı ve iskân organizasyonu da ortaya çıkmaktadır. Değişen bu kırsal üretimin bir çıktısını da dönüşmüş / yeni mesken tipleri oluşturmaktadır. Dolayısıyla "yüzen evler" olgusu tam olarak bu yeni üretim biçimiyle ortaya çıkmış, modern çağ ve profesyonelleşmiş tarım uygulamalarının doğal bir sonucudur.

Yüzen evler, Türkiye'deki örnekleriyle geleneksel bir balıkçı yerleşmesi olan dalyanların karadan (kıyıdan) suya taşınmış ve kısmen özgün, kısmen dönüşmüş bir türevidir. Niteliksel ve fonksiyonel yaklaşımlarla yüzen evler tamamen dalyanların işlevlerine sahiptir. Tunçdilek'e göre dalyanlar; balıkçılık faaliyeti için oluşturulmuş tesislerdir. Aynı zamanda bu tesisler genellikle erkeklerin çalıştığı bir iş yeridir. $\mathrm{Bu}$ iş yerinin sakinleri çoğunlukla bölgeye yabancı kişilerdir ve bu yerleşmeler geçici / dönemsel olarak kullanılmaktadır (Tunçdilek, 1967: 160-161). Benzer bir yaklaşımla, kültür balıkçıllğı faaliyetine özel olarak vurgu yapan Taş’a göre de yüzen evler, nitelik ve fonksiyonel olarak tipik bir dalyan yerleşmesidir (Taş, 2016: 247). Ancak yüzen evler yapı malzemesi olarak geleneksel dalyan yerleşmelerinden oldukça farklıdır (Bkz. Doğanay, 1994: 310).

Yerleşme Coğrafyası açısından okyanuslar, denizler, göller ve akarsular yerleşmeyi sınırlayan etkenler olarak değerlendirilmektedir. Bu değerlendirme günümüzde büyük ölçüde geçerli olmakla birlikte, gelişen teknoloji ve artan ihtiyaçlara bağlı olarak, yerleşmeyi sınırlandıran bu coğrafi birimler, bir süredir yüzen evler ile dünyanın farklı yerlerinde kısmen yerleşime açılmıştır. Başka bir anlatımla, "ekümen"in sınırı genişlemektedir (Bkz. Gümüş̧̧ü, 2014: 288-289). Günümüzde yüzen evler; yeni ihtiyaçlarla, yeni mimari yaklaşımlarla ve yeni hukuki mevzuatlarla dünyanın çeşitli yerlerinde yaygınlaşmaktadır.

\section{3. Çalışmanın Amacı}

Ülkemizin denizlerinde ve Keban Baraj Gölü’nde örneklerini gördüğümüz yüzen evler, özellikle Yerleşme Coğrafyası açısından oldukça ilgi çekici, kısmen özgün kırsal yerleşmelerdir. Gelecekte bu mesken türünün dünyada ve ülkemizde iskân, turizm gibi nedenlerle kitlesel bir ilgi ile karşılaşacağı görülmektedir. Kitleselleşmeye açık bu yerleşme türünün etkileneceği süreçleri ve nasıl evrileceğini bugünden kestirmek güçtür. Olgu, mimari / mühendislik, ekonomik, sosyal, hukuki, çevresel boyutlarıyla gelecekte pek çok disiplinin ama özellikle Yerleşme Coğrafyası'nın gündeminde daha fazla yer tutacaktır. Bu bağlamda çalışmamızın amacı; yüzen evler gibi güncel bir coğrafi gelişmenin dinamiklerini incelemek, küresel ve yerel görünümünü irdelemek ve Keban Barajı'ndaki örnekleriyle bu yeni mesken türünün değerlendirilmesine katkı sunmaktır. 


\section{Keban Baraj Gölü’nde Yüzen Evler}

Meskenlerin fonksiyonları ve yapım nedenleri, dünyanın hemen her yanında birbirine benzemektedir. Tanoğlu'na göre; iskân ve iskânın bir unsuru olan meskenden gaye; soğuk, sıcak, yağmur ve kar gibi hava tesirlerine ve yırtıcı hayvan ve diğer insanlardan gelebilecek dış tehlikelere karşı can ve malı emniyete almak, tabi veya suni, az çok kapalı bir sığınakta yemek, dinlenmek ve bilhassa uyumaktır. Uyku ihtiyacı ve bu ihtiyacı gidermek üzere bir barınak temini ve bu barınağa her gün belirli zamanlarda sı̆̆ınmak gidip gelmek zorunluluğu, tıpkı beslenme gibi, hiçbir insan varlığının kaçınamayacağı ihtiyacıdır. Kaldı ki, İskan Coğrafyası'nda mesken denince, en basit avcı, balıkçı veya bekçi kulübesinden şehirlerin en mütekamil ev ve apartmanına kadar sadece ikametgâh olarak kullanılan yapılar değil, ambar, ahır, samanlık, hangar, atölye, mağaza, okul, cami, kilise, kışla, tiyatro, sinema gibi ticari, sınai, dini, askeri, kültürel veya eğlence ihtiyaçlarını karşılamak üzere vücuda getirilen bütün binalar, anlamak gerekmektedir (Tanoğlu, 1954: 1-2).

Ekonomik etkinlikler yerleşmelerin varlığını sürdüren, dönüştüren ve geleceğini belirleyen dinamik bir etkendir. Üretimin doğal bir parçası olan kır yerleşmelerinde bu ilişki çok daha belirgindir. Hatta kır iskanı; bağ, bahçe, mera gibi üretimin tüm unsurlarıyla "organik bir vahdet" oluşturmaktadır (Tanoğlu, 1954: 11). Kırsal hayatın ekonomisi; doğayla iç içe sürdürülen, üretimin türüne göre dönemsel olarak 24 saat devam edebilen faaliyetlerin toplamıdır. Kır ekonomisi aynı zamanda kırsal hayatın her hücresine işlemiş bir yaşam biçimidir. Dolayısıyla kırsal hayatın hemen her bir unsuru, üretimin de bir parçasıdır. Bu bağlamda kırsal mesken, kırsal uğraşının doğal bir uzantısı, aynı zamanda bir üretim aracıdır. Dolayısıyla kırsal ekonomik uğraş, kır meskenin biçimini de belirlemektedir. Tanoğlu'na göre, bağcının, zeytincinin, tütüncünün evleri başka başkadır. Böylece mesken ve mesken toplulukları bir memleket medeniyetinin olduğu kadar, aynı zamanda o memlekette hâkim faaliyetin, hayat tarzı ve ekonomi şeklinin de makesleridir ve bu itibarla da en mükemmel coğrafi vakalardır (1954: 2-11).

Türkiye'nin ilk hidroelektrik amaçlı barajlarından biri olan Keban Baraj Gölü, 1965-1974 yıllarında Fırat Nehri üzerine inşa edilmiştir. Atatürk ve Karakaya barajlarından sonra Türkiye'nin üçüncü büyük barajıdır. Maksimum gölalanı 681 km²' dir. Baraj, ülkemizin balık üretimine katkı yapan önemli “iç su”larındandır. Çalışma alanında kültür balıkçılığı, ağ-kafeslerin ilk kurulduğu 2000 yılından itibaren, hızlı bir gelişim göstermiştir. Keban Barajı, Türkiye kültür balıkçılığında \% 9, iç sularda ise \% 16'lık üretim payına sahiptir. Keban Barajı'nda 2004 2014 yılları arasında tesisleşmenin önemli bir büyüme kaydettiği, özellikle 2010 yılında işletme sayısının neredeyse iki kat arttığı dikkati çekmektedir (Güner, 2015: 2-3). Baraj gölünde kültür balıkçılığının zaman içinde daha profesyonel bir uğraş haline gelmesiyle, çiftliklerin teknolojik donanımında ve kalıcı yatırımlarında artış gerçekleşmiştir. Nitekim yüzen evlerin ilk örnekleri de, işletme sayılarının hızla arttığı 2010 yılında görülmüştür.

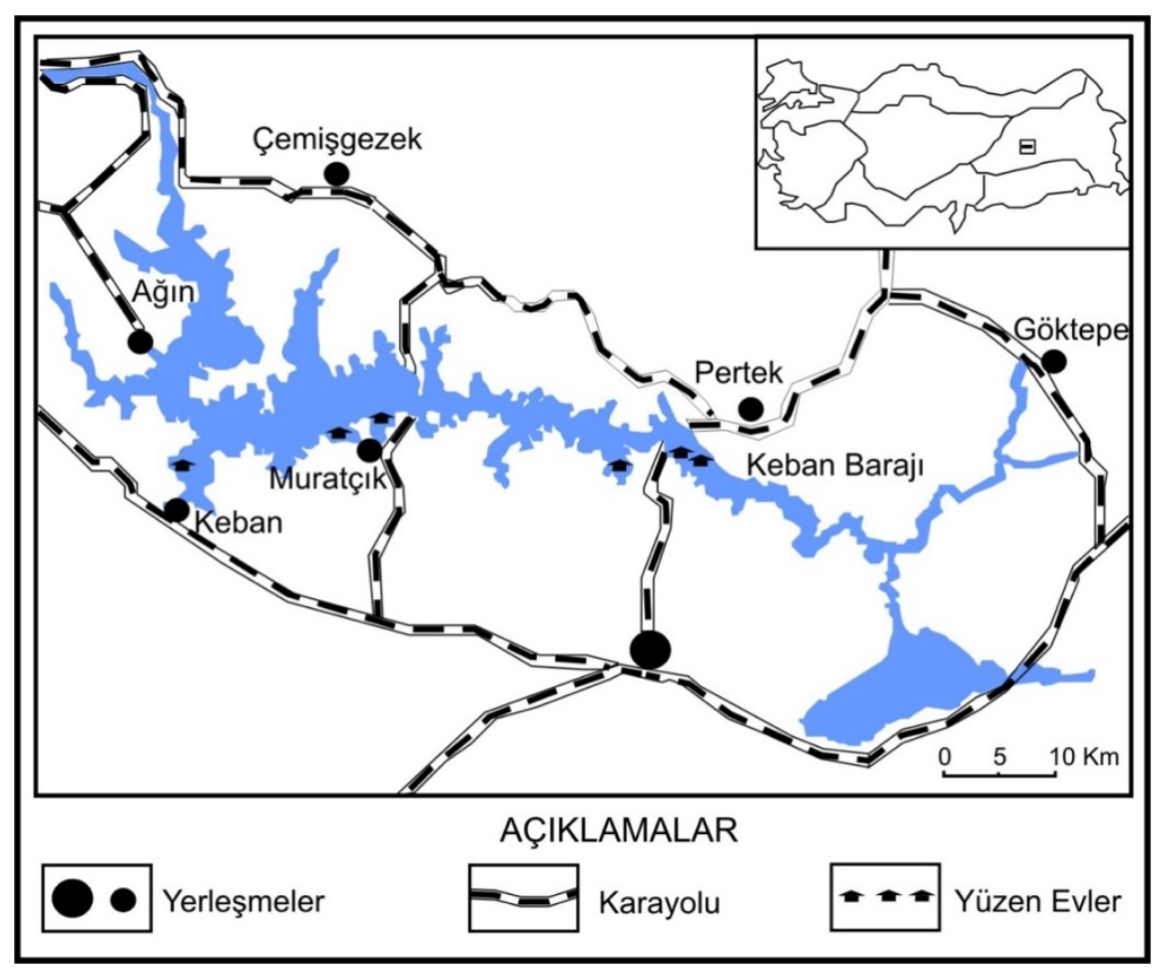

Şekil 1: Keban Baraj Gölü'nün lokasyonu ve yüzen evlerin dağılış1 
Keban Barajı'nda yüzen evler, TKDK’nın (Tarım ve Kırsal Kalkınmayı Destekleme Kurumu) “Çiftlik Faaliyetlerinin Desteklenmesi ve Modernizasyonu "kapsamında "servis platformu" veya "bekçi kulübesi" olarak hibe programı ile desteklenmektedir. Programın yürürlüğe girdiği 2015 yılından itibaren çalışma alanında yüzen ev inşası hız kazanmıştır (TKDK, 2019a), (TKDK, 2019a). Yüzen evler daha çok tesislerin kümeleştiği Elazı̆̆Pertek iskelelerinin çevresinde, Elazığ Muratçık köyü çevresinde ve Baraj seti yakınında yoğunlaşmaktadır (Şekil 1). Ayrıca barajın hemen her yanında münferit yüzen evlere de rastlanmaktadır. Bugün barajda çeşitli tipte ve büyüklükte 70 civarında yüzen ev bulunmaktadır. Yüzen evler, balık çiftliklerinin alandaki yoğunluğuna bağlı olarak görece bir arada /toplu ya da münferit /dağınık halde bulunmaktadır (Foto 1), (Foto 2).

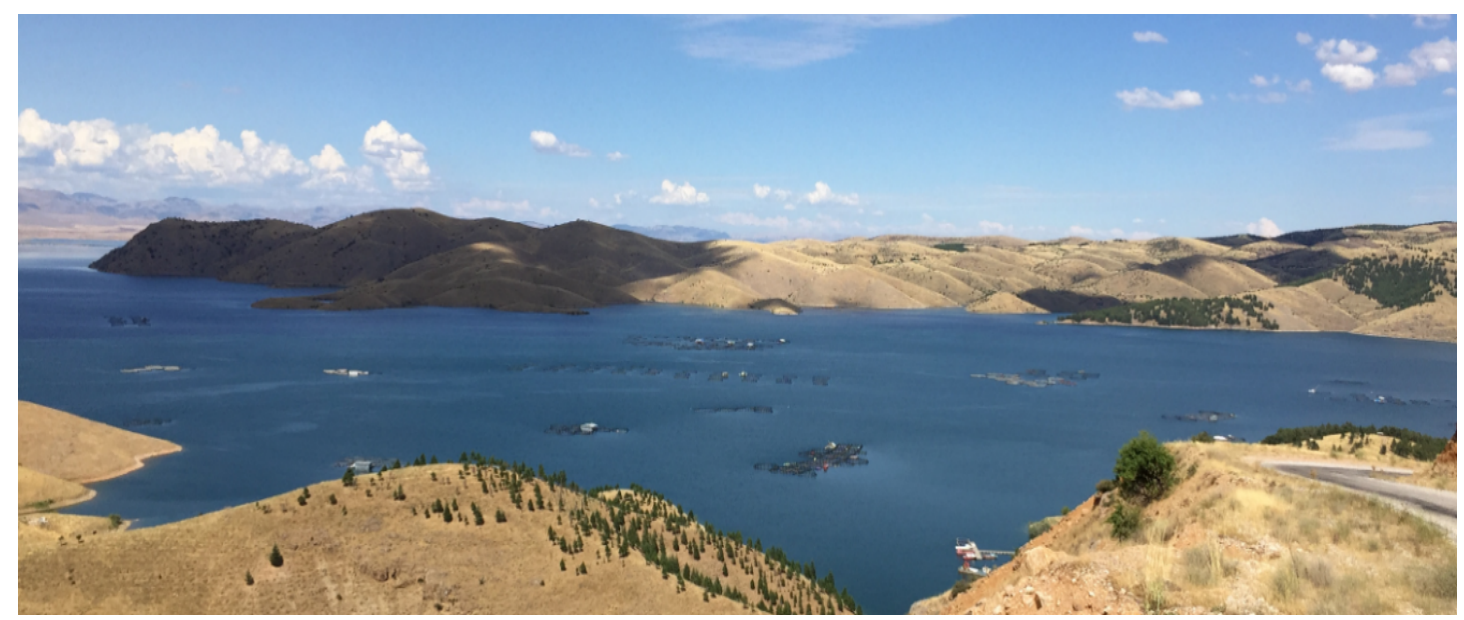

Foto 1: Evlerin kümeleştiği bir koy (baraj set bölgesi yakını)

Keban Barajı'nda yüzen evlerin iki ana işlevi bulunmaktadır. Birinci işlev; çalışanların barınma ihtiyacının karşılaması, ikinci işlevi ise yem ve balıkçılık faaliyetinin gerektirdiği malzemelerin depolanmasıdır. Yüzen evler özellikle karada (kıyıda) lojistik tesisine sahip olmayan çiftlik işletmelerince ilgi görmektedir. Balık üretiminin gerçekleştirildiği Ekim-Haziran aylarını kapsayan 9 aylık süre içinde, yemleme ve kontrol amacıyla bazen günde iki kez balık kafeslerine ulaşım gerekmektedir. Sürekli olarak karayolu ve devamında tekne kullanılarak kafeslere günlük ulaşım sağlamak, hem maliyeti artırmakta hem de çalışanlar açısından zorluklar doğurmaktadır. Yüzen evler, çalışanlara sağladığı barınma ve lojistik imkânlarıyla, kafes - kara bağlantılı günlük hareketliliği, 10-15 güne çıkarmaktadır. Bu nedenle bazı işletmeler, kıyı tesislerine sahip olsa da, kıyıdan uzak kafesleri için yüzen ev kullanımını daha pratik ve ekonomik bir seçenek olarak tercih etmektedirler.

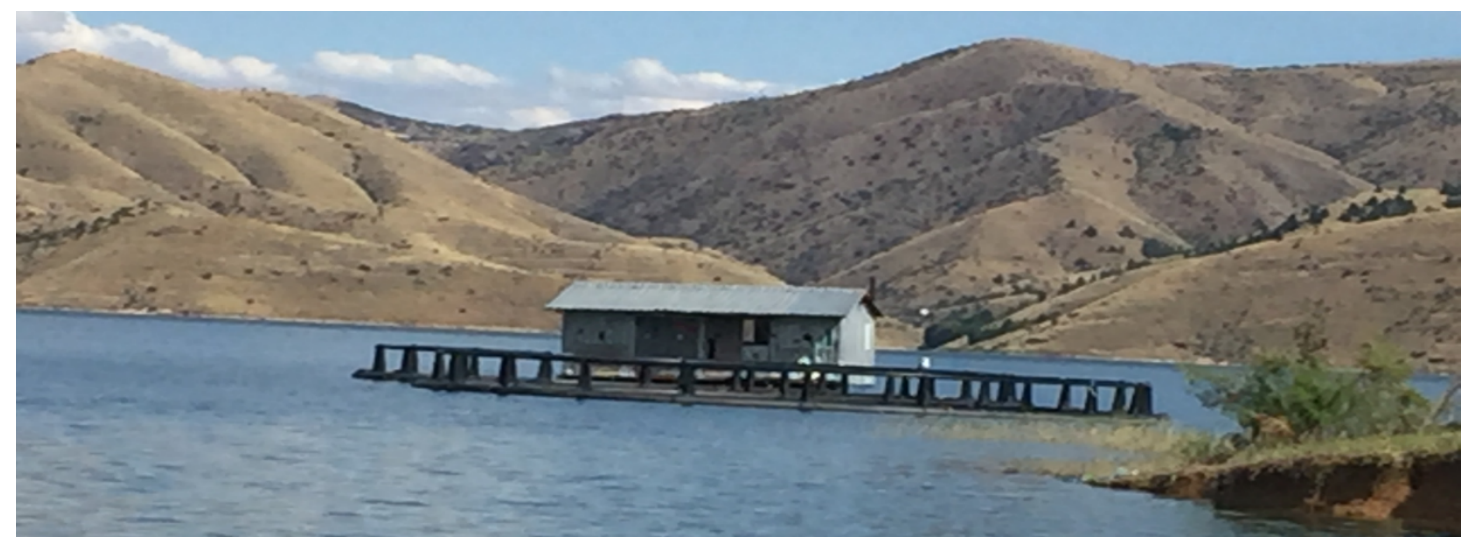

Foto 2: Münferit bir yüzen ev

Öte yandan kültür balıkçılığı maliyetli bir uğraştır. Bu nedenle balık kafesleri için oluşabilecek çeşitli riskleri bertaraf etmek hayati önemdedir. Örneğin kafes ağlarının hava şartları gibi doğal ya da beşeri etkenlerden zarar görmesini engellemek gerekmektedir. Dolayısıyla özellikle kıyıdan uzak kafeslerin güvenliğini sağlamak amacıyla yüzen evlere ihtiyaç duyulmaktadır.

Çalışma alanında bulunan yüzen evlerin inşası Elazığ'da bulunan atölyelerde gerçekleşmekte, yapı malzemeleri ise Elazığ, Muğla ve İzmir'den temin edilmektedir. Modern bir yüzen evin inşasında yapı malzemesi 
olarak demir aksam, strafor, ahşap, şamandıra ve plastik malzemeler kullanılır. Demir iskelete, duvar malzemesi olarak genellikle strafor giydirilir, plastik ve ahşap (daha iptidai yapılarda sac) malzeme, dış kaplama olarak kullanılır. İnşa edilen evler, suyun üstünde hareket edebilen bir yüzer platform üzerinde yer alır. Yüzer platformlar ise demir aksam üzerine strafor plakaları veya şamandıralar kullanılarak inşa edilir (Foto 3). Yüzer platform, doğal olarak üzerine yer alan evden geniş olmak zorundadır. Yüzer platformların kapladıkları alan $50 \mathrm{~m}^{2}$ ile $120 \mathrm{~m}^{2}$ arasında değişirken, evlerin alanı genellikle $30 \mathrm{~m}^{2}$ ile $90 \mathrm{~m}^{2}$ arasında değişmektedir.

İnşa edilen evler, tekne ile istenen yere çekilir. Evlerin dalga ve rüzgarla hasar görmemesi için, gemilerin demir atmasına benzer bir biçimde, yüzer platformun 4 yanından 1-2 ton ağırlığında beton bloklar suya indirilir (Şekil 2), (Foto 4). Kafesler genellikle evin çevresinde yer alır. Yüzer platform, evin 4 yanını çevreleyerek, bir nevi veranda (sundurma-balkon) işlevi görür (Şekil 3). Yüzen evlerin verandası balıkçılık faaliyeti için oldukça gereklidir. Veranda, hasat zamanlarında da balıkların kafesten çıkarılması ve istiflenmesinde kullanılır. Kafes ağları, vinç yardımıyla boşaltılır. Bu vinç ya tekneye ya müstakil bir yüzer platforma ya da yüzen evin verandasına monte edilerek kullanılır.

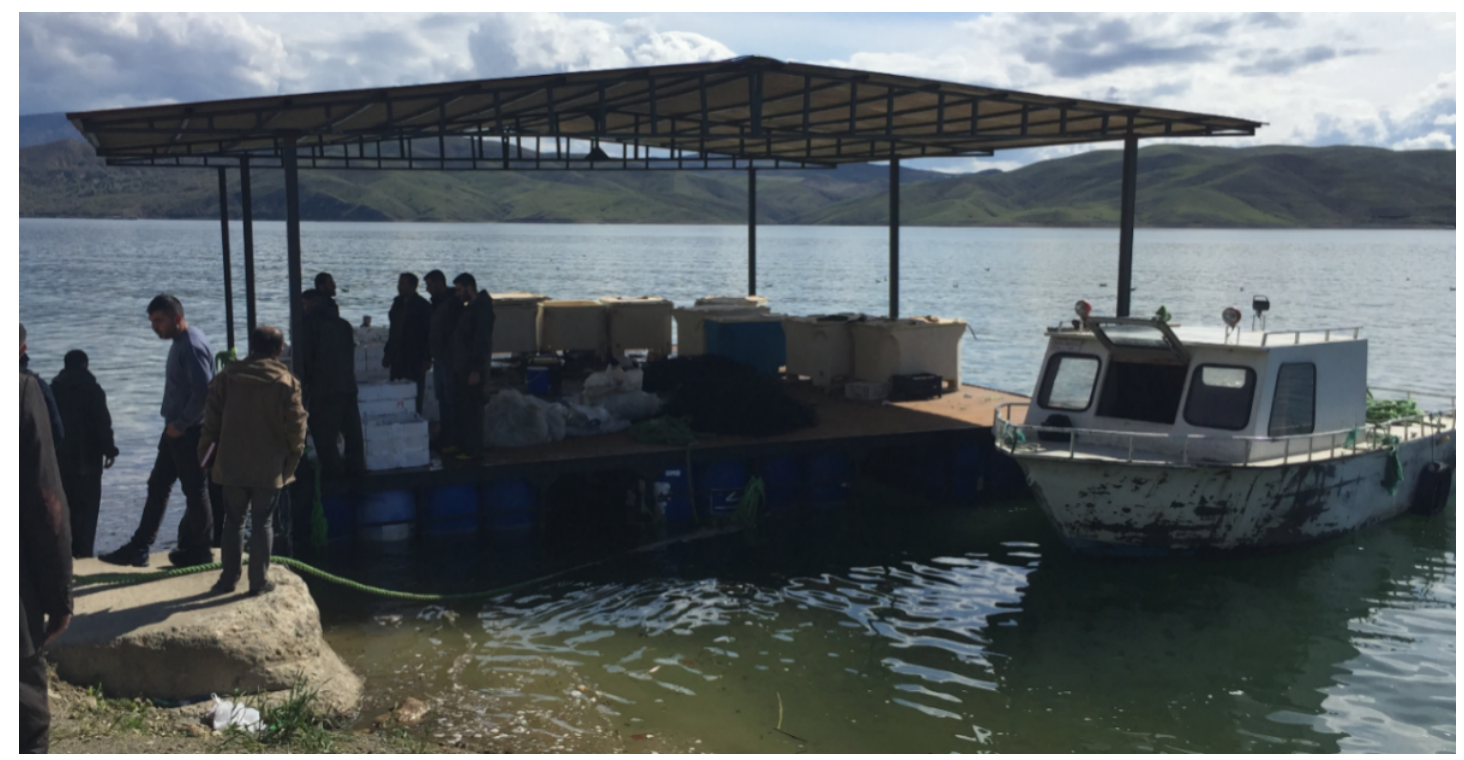

Foto 3: Daha çok hasat zamanında kullanılan ve tekne aracılığıyla hareket ettirilen müstakil bir yüzer platform. Evler bu ve benzeri platformlara inşa edilir

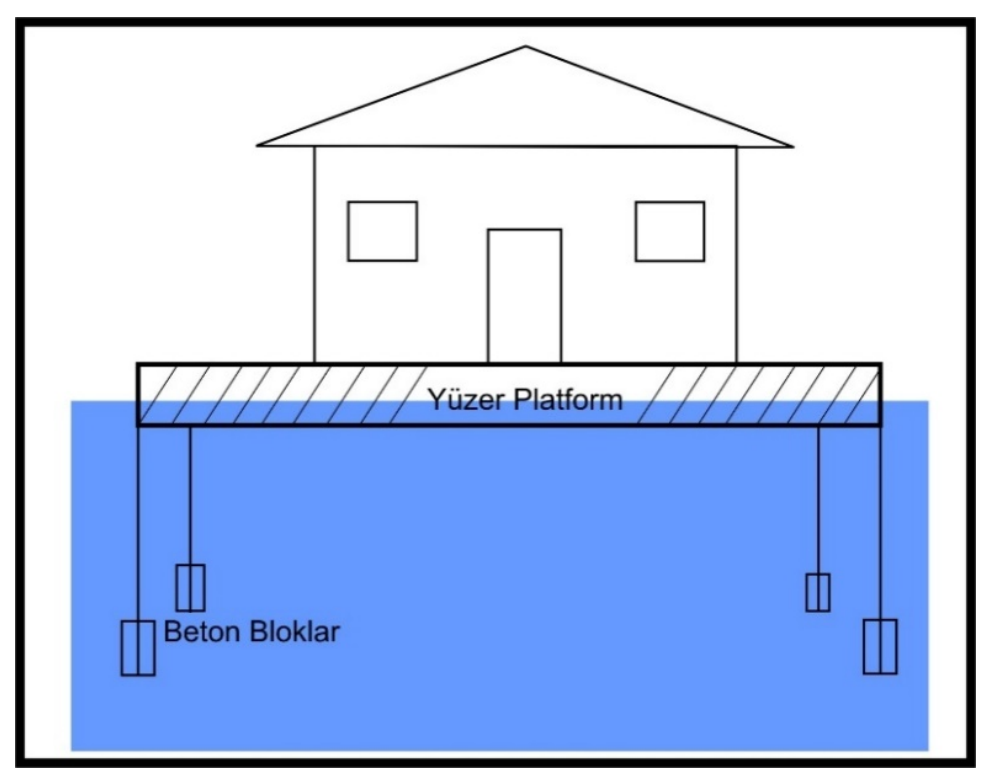

Şekil 2: Yüzen ev profili 
Hava şartları ve su sıcaklığı, kültür balıkçılığı için belirleyici etkenlerdir. Y1l içinde balıkçılığın yapılacağ1 süreyi ve dönemi bu iki etken belirler. Balık kafeslerinin ve dolayısıyla yüzen evlerin yıl boyunca bulunacağı konumu da özellikle hava şartları (rüzgar) belirler. Çalışma sahasının kuzeyinde uzanan ve 3500m.yi aşan yüksek Munzur Dağları'ndan, $850 \mathrm{~m}$. civarındaki Keban Baraj Gölü’ne doğru zaman zaman şiddetli hava akımları gerçekleşmektedir. Bu nedenle Keban Barajı'nda kuzey sektörlü rüzgarlar yılın büyük bölümünde etkilidir. Rüzgarlar özellikle sonbahar ve ilkbahar aylarında şiddetlenmektedir (Tonbul, 1990: 276-280), (Günek, 1999: 368-371), (Atasoy ve Çitçi, 2009: 39-40). Bu nedenle kafesler/meskenler daha çok koy benzeri korunaklı alanlarda kümelenirler.

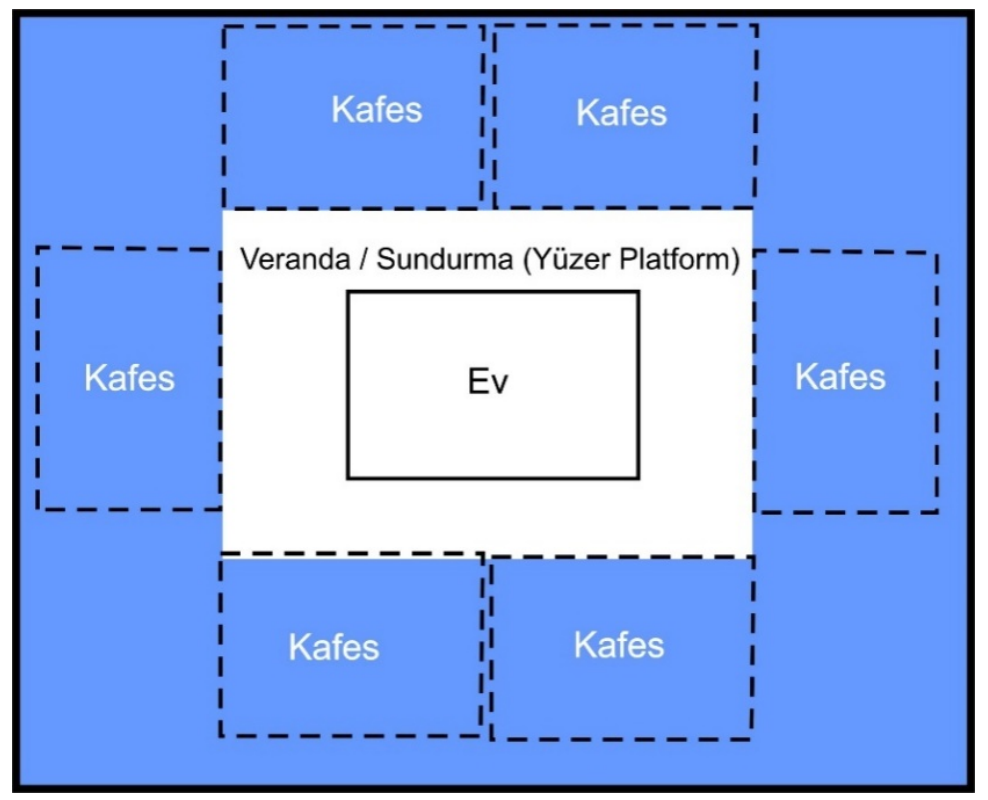

Şekil 3: Yüzen ev ve çevresi

Kafeslerin ve dolayısıyla meskenlerin barajdaki dağılışını etkileyen bir diğer faktör karayoludur. Kafeslerin yeri belirlenirken veya ihtiyaca bağlı olarak yer değiştirdiğinde seçilen alternatif alanlar belirlenirken, kriterlerden biri karayoluna yakınlıktır. Çünkü kafeslerin karayoluna yakınlığı, ürünün pazara arzında ve ihtiyaç duyulan lojistik sevkiyatının karşılanmasında maliyetleri düşürmektedir.

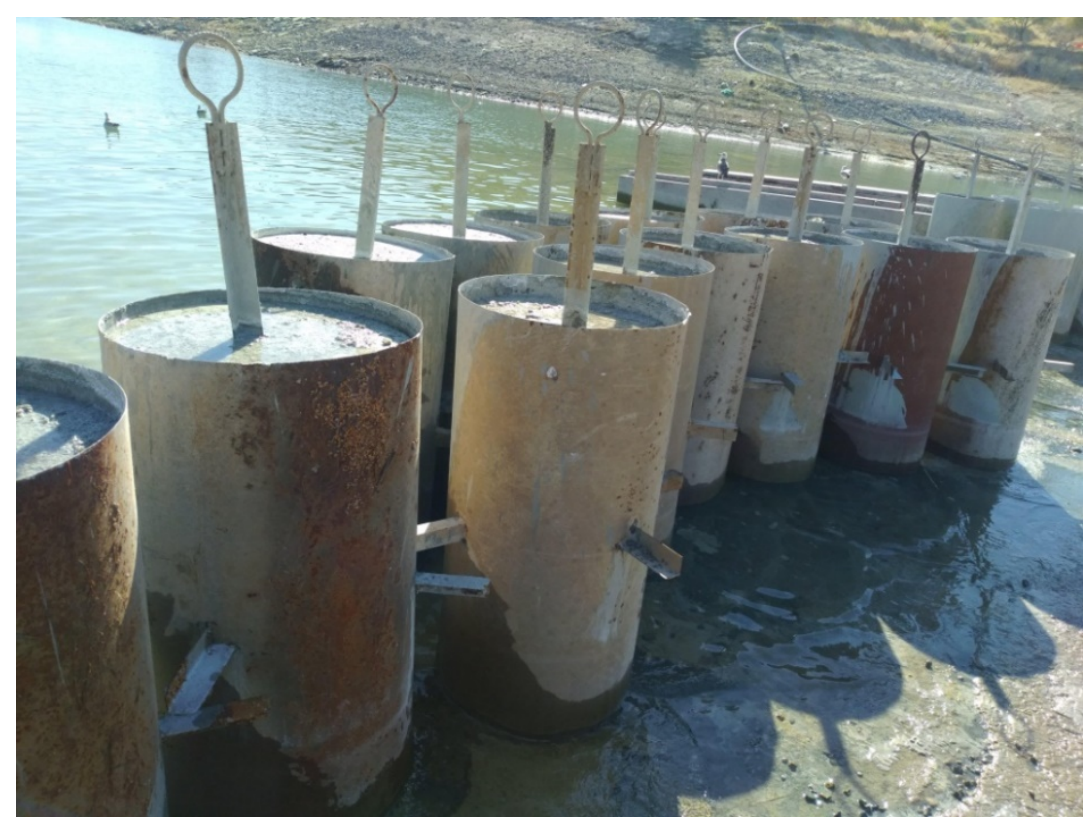

Foto 4: Yüzer platformu dengelemek için kullanılan beton bloklar 
Yüzen evlerin, balıkçılık faaliyetinin gerektirdiği özel bir mimari gereksinimi, plan ya da yapı malzemesi bulunmamaktadır. Yüzen ev asgari olarak depo-barınma gibi iki ana işlevi sağlıyorsa, işletmeler açısından yapım amacına ulaşılmıştır. Yüzen evlerin fonksiyonelliğini ve kullanışlığını artıran esas unsur donanımıdır. Çalışma alanında bazı meskenler; güneş panelleri ile elektrik enerjisi ihtiyacının karşılandı ̆̆ı, kullanım suyunun daha steril olması için 40 metre derinden çekildiği, elektrik ve dizel yakıtın birlikte kullanıldığı 1sıtma sistemlerine sahip konforlu yapılardır (Foto 5). Buna karşın yine çalışma alanında ancak kısa sürelerle kullanılabilecek daha basit yapılı barınaklarda bulunmaktadır (Foto 6).

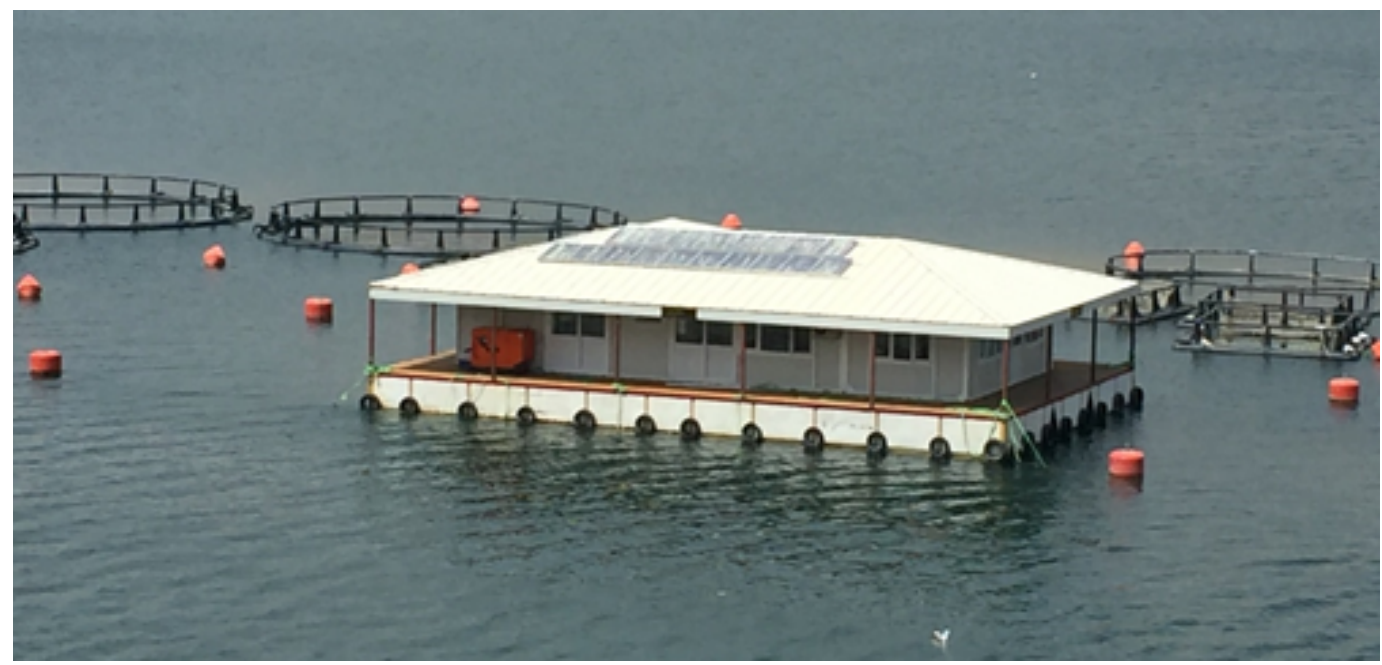

Foto 5: Güneş panelleri, gelişmiş ısıtma ve su sistemleri ile donanımlı bir yüzen ev

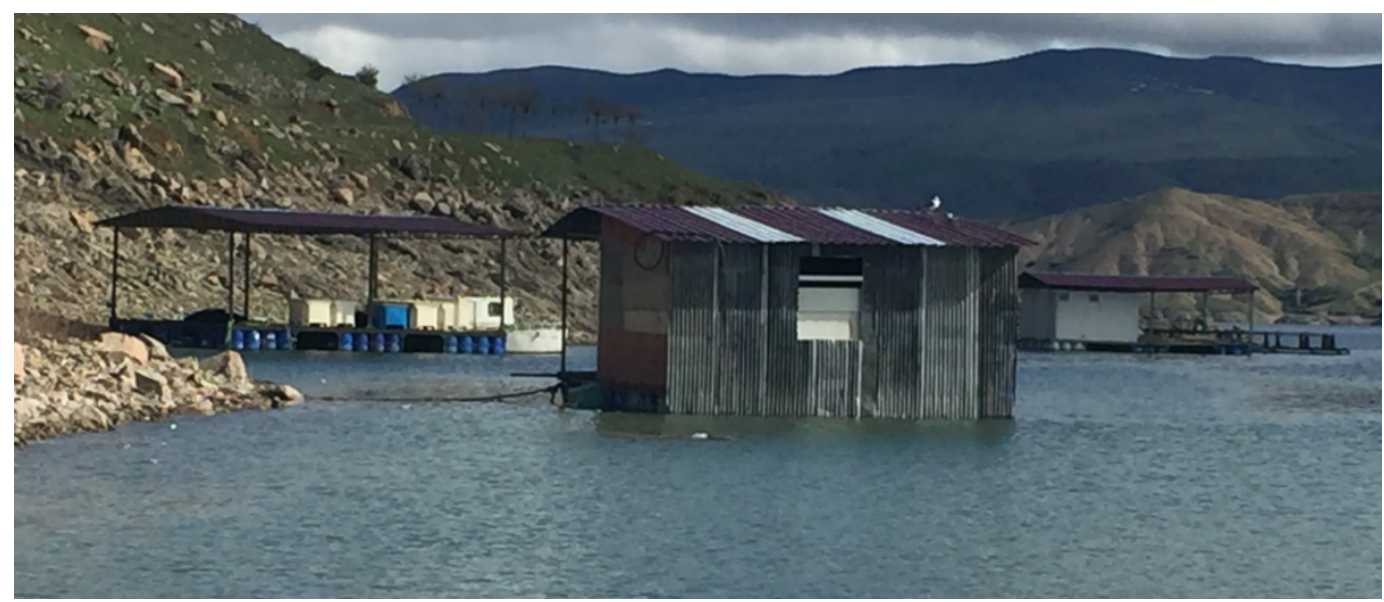

Foto 6: Sac malzemenin yoğun kullanıldığg basit yapılı bir yüzen ev

\section{Sonuç}

Çağımızda insan yerleşmesini sınırlayan pek az coğrafi engel bulunmaktadır. Çöllerden kutuplara, denizlerden dağların zirvelerine kadar yeryüzünün hemen her parçası insanın yaşam ve yerleşimine açık haldedir. Yüzen evler olgusu bu gelişmelerin güncel bir örneğidir. Her halükârda bir kara kavramı olan "mesken"in, "su" üzerindeki örneklerinin artması, bugün için istisnai bir görünüm oluştursa da, fütürist bir yaklaşımla, bir vadede küresel bir yaygınlık ve işlevsellik kazanacağı açıktır. Bu çerçevede Yerleşme Coğrafyası açısından nehirler, göller ve denizlerin yerleşmeyi sınırlandırdı ̆̆ı paradigması yeniden değerlendirilmelidir.

Yüzen evler dünyada görülen örnekleriyle birbirinden çok farklı özelliklerdeki ülkelere, toplumlara, kültürlere bir biçimde hitap etmektedir. İklim değişmelerinden tarımsal faaliyetlere, turizmden hızlı kentleşmeye kadar pek çok olgu bu meskenlerin kırsal ve kentsel biçimlerde yaygınlaşmasına katkı sağlamaktadır. Yüzen evler; ABD, İngiltere, Hollanda ve Filipinler'de daha çok kentsel konut olarak kullanılmaktadır. Türkiye'de geçici, Kamboçya'da daimi olarak kullanılan, balıkçılık faaliyeti gereğince inşa edilmiş kırsal yerleşmelerdir. Bu bağlamda yüzen evler çok yönlü kullanıma sahiptir. Dünyadaki örnekleriyle daha çok köy /site /mahalle /semt 
gibi “toplu” yerleşim özelliği gösteren yüzen evler, Türkiye'deki örnekleriyle münferit / “dağınık” bir yerleşme dokusuna sahiptir.

Türkiye'nin farklı farklı denizlerinde ve göllerinde bugün için mevcut bulunan hemen her yüzen ev, geleneksel bir iskân şekli olan "dalyan” yerleşmesi olsa da dünyadaki kullanım çeşitliliğiyle ayrı bir iskân kategorisidir. Çünkü yüzen evler, fonksiyonel olarak çok fazla çeşitliliği olan, yerel ve bölgesel niteliklerle şekillenen, kırsal / kentsel biçimlere sahip, kendine özgü bir mesken türüdür.

Kültür balıkçılığı dünyada son 50 yılda gelişen "yeni” bir ekonomik faaliyettir. Her üretim faaliyetinde olduğu gibi kültür balıkçılığı da, üretiminin gereği bir yaşam biçimi doğurmaktadır. Bu yaşam biçimi ise zamanla başka sonuçlar doğurmaktadır. Keban Baraj Gölü, kültür balıkçılığının son yıllarda geliştiği ve profesyonel bir uğraş haline geldiği “iç su”larımızdandır. Barajda yıllar boyunca balıkçılık faaliyetleri hız kazanmış, tesisleşme artmıştır. Bu tesisleşmenin bugün önemli bir unsuru, balıkçılık faaliyetlerinin bir parçası haline gelen yüzen evlerdir. Yüzen evler, yetiştirilen balıkların günlük bakımı, balık kafeslerinin güvenliği ve hasat dönemlerindeki işlevselliği nedeniyle ilgi görmektedir.

Ülkemizde, yüzen evlerin yaygınlaşmasına bağlı olarak yakın bir gelecekte çeşitli çevresel ve hukuki sorunların ortaya çıkacağı görülmektedir. Ayrıca dünyada gelişen eğilime paralel olarak, ülkemizde de yüzen evlerin, balıkçılık faaliyeti dışında, diğer kullanım türlerine de ilginin artması muhtemeldir. Bugün dünyada pek çok yönüyle tartışılan yüzen evler olgusu, Keban Barajı örneğinde görüldüğü biçimiyle, ülkemizde de en azından hukuki boyutu ve çevresel yönüyle tartışılmasını ve gereken önlemlerin bugünden alınmasını zorunlu kılmaktadır.

\section{Kaynaklar}

Ambica, A., Venkatraman, K. (2015) "Floating Architecture: A Design on Hydrophilic Floating House for Fluctuating Water Level”. Indian Journal of Scienceand Technology, Vol 8 (32), pp: 1-5 (07.06.2019 tarihinde https://www.researchgate.net/publication/300003594_Floating_Architecture_A_Design_on_Hydrophili c_Floating_House_for_Fluctuating_Water_Level adresinden alınmıştır)

Atasoy, A., Çitçi, M.D. (2009) "Değişen İklim Koşullarının Elazı̆̆ Ovası ile Yakın Çevresinin Ekosistemine Etkileri”. Doğu Coğrafya Dergisi, C:14 (21), s: 33-52, Erzurum

Dambite, D. (2011) "Floating Houses As Real Propertyin Latvia - Legal Aspects", BALTIC SURVEYING 11 International Scientific Conference of Agriculture Universities of Baltic States 11th - 13th of May 2011, Jelgava, Latvia, pp: 72-77, (05.06.2019 tarihinde https://llufb.llu.lv/conference/Balticsurveying/BALTIC-SURVEYING-2011-72-77.pdf adresinden alınmıştır)

Doğanay, H. (1994), “Türkiye Beşeri Coğrafyası”, Gazi Büro Kitabevi, Ankara

Garfield, L (2017) "These \$2 million floating homes are designed to withstand Category 4 hurricanes", (07.06.2019 tarihinde https://www.businessinsider.com/floating-homes-hurricanes-waterstudio-solar2017-11 adresinden ulaşı1mıştır)

Gümüşçü, O. (2014) “Coğrafyaya Davet”, Yeditepe Yayınevi, İstanbul

Günek, H. (1999) “Harput ve Elazı ̆̆ Şehrinin İklim Elemanlarının Karşılaştırılması ve İklim Koşullarının Çevresel Etkileri”. TDV, Dünü ve Bugünü ile Harput. C:II, s: 366-386

Güner, B. (2015) “Keban Baraj Gölü’nde Kültür Balıkçılığı”, Fırat Üniversitesi Sosyal Bilimler Dergisi, C: 25 , (1), s: 1-8, Elazı̆

Ishaque, F., Ahamed, M.S., Hoque, M.N. (2014) Design and Estimation of Low Cost Floating House. International Journal of Innovationand Applied Studies, Vol. 7 No. 1 ,pp: $49-57$ (03.06.2019 tarihinde https://www.researchgate.net/publication/264608633_Design_and_Estimation_of_Low_Cost_Floating_ House adresinden alınmıştır)

MDDPC, (2010) “A Planing Report: Lawand Policy Regarding Floating Homes, Final Report “| September 2010 Coastal Technical Assistance Program, Middle Peninsula Planning District Commission (29.05.2019 tarihinde http://mppdc.org/articles/reports/final_floating_homes.pdf adresinden alınmıştır)

Moon, C. (2015) “A Study on the Floating House for New Resilient Living”, Journal of the Korean housing association, Volume 26 Issue 5, pp: 97-104 (27.05.2019 tarihinde https://www.researchgate.net/publication/285635430_A_Study_on_the_Floating_House_for_New_Resilient _Living adresinden alınmıştır) 
Naing, N., Santosa, H.R., Soemarno, I. (2011) "Creating a Better Living Condition at the Floating House in Lake Tempe”, Special Track 18th CIB World Building Congress May 2010 Salford, United Kingdom, pp: 6375 (06.06.2019 tarihinde http://www.irbnet.de/daten/iconda/CIB18944.pdf adresinden alınmıştır)

Ramsey, A., Rasmioen, N., Sonneveld, M. (2018) “Floating Homes Philippines Project Plan”, (01.06.2019 tarihinde https://d1rkab7tlqy5f1.cloudfront.net/Websections/Infrastructures\%20and\%20Mobility/Student\%20proj ecten/Floating\%20homes\%20Phillipines/Project\%20plan\%202.2.pdf adresinden alınmıştır)

Resmi Gazete, (2007) “Denizlerde Balık Çiftliklerinin Kurulamayacağı Hassas Alan Niteliğindeki Kapalı Koy ve Körfez Alanlarının Belirlenmesine İlişkin Tebliğ’, (17.05.2019 tarihinde http://www.resmigazete.gov.tr/eskiler/2007/01/20070124-10.htm adresinden ulaşılmıştır)

Schroder, Y. (2015) "Floating Homes", pp: $44-49 \quad(14.05 .2019 \quad$ tarihinde https://www.wingas.com/fileadmin/Wingas/content/06_Presse_Mediathek/Gaswinner/2015_03/PDF/GW0315_EN _44-49_Klimawandel.pdf adresinden ulaşılmıştır)

Paratic, (2016) “Balık Üretim Çiftliği Kurarak Para Kazanmak”, (04.06.2019 tarihinde https://paratic.com/balik-uretim-ciftligi-kurarak-para-kazanmak/ adresinden ulaşılmıştır)

Steemit, (2017) "Çin'in Yüzer Balık Çiftlikleri”, (21.05.2019 tarihinde https://steemit.com/kusadasi/@burock/cin-in-yuezer-balik-ciftlikleri adresinden ulaşılmıştır)

Sözcü Gazetesi, (2017) “Türk Kültür Balıkçılığı İhracatı 800 Milyon Doları Aştı”, (20.05.2019 tarihinde https://www.sozcu.com.tr/2017/ekonomi/turk-kultur-balikciligi-ihracati-800-milyon-dolari-asti2096861/ adresinden ulaşılmıştır)

Taş, B. (2016) Türkiye 'nin Kırsal Yerleşmeleri, Yeditepe Yayınları, İstanbul

Tanoğlu, A. (1954) İskân Coğrafyası, Esas Fikirler, Problemler ve Metot. Türkiyat Mecmuası, C: XI, s: 1-82, İstanbul

TKDK, (2019a) “Tarım ve Balıç̧ılık Ürünlerinin İşlenmesi ve Pazarlanması ile İlgili Fiziki Varlıklara Yönelik Yatırımlar", (04.06.2019 tarihinde https://www.tkdk.gov.tr/Content/File/BasvuruFiles/BasvuruPaketiHazirlamaDokumanlari/UygunHarca malarListesi/1034/10342UygunHarcama.pdf adresinden ulaşılmıştır)

TKDK, (2019b) “Çiftlik Faaliyetlerinin Çeşitlendirilmesi ve İş Geliştirme” (04.06.2019 tarihinde https://www.tkdk.gov.tr/Content/File/BasvuruFiles/BasvuruPaketiHazirlamaDokumanlari/UygunHarca malarListesi/3025/30251UygunHarcama.pdf adresinden ulaşılmıştır)

Tonbul, S. (1990) Elazı̆̆ ve Çevresinin İklim Özellikleri ve Keban Barajının Yöre İklimi Üzerine Olan Etkileri, Firat Üniversitesi Coğrafya Sempozyumu, 14-15 Nisan 1986, s: 275-293, Elazı ̆̆

Tunçdilek, N. (1967) Türkiye İskân Coğrafyası-Kır İskanı, İ.Ü. Edebiyat Fak. Yay. No: 1283, Coğrafya Enst. Yay. No: 49, İstanbul 
“Yüzen Evler” Olgusuna Genel Bir Bakış ve Keban Baraj Gölü Örneği 